\title{
Survival of Gibberella zeae in Fusarium-Damaged Wheat Kernels
}

\author{
Sharon A. Inch and Jeannie Gilbert, Cereal Research Centre, Agriculture and Agri-Food Canada, 195 Dafoe \\ Road, Winnipeg, Manitoba, Canada R3T 2M9
}

\begin{abstract}
Inch, S. A., and Gilbert, J. 2003. Survival of Gibberella zeae in Fusarium-damaged wheat kernels. Plant Dis. 87:282-287.

The survival of Gibberella zeae in Fusarium-damaged kernels was investigated under field conditions at Glenlea, Morden, Portage la Prairie, and Winnipeg, Manitoba, Canada. Fusariumdamaged kernels were either left on the soil surface or buried at 5 or $10 \mathrm{~cm}$ and monitored for 24 months. G. zeae was isolated after 24 months from Fusarium-damaged kernels under all conditions, with isolation frequency ranging from 85 to $99 \%$ of kernels. Perithecia developed on Fusarium-damaged kernels from all locations and treatments, but ascospores developed only in perithecia on kernels located at the soil surface. A similar experiment was conducted under controlled conditions to test survival of the fungus in kernels left at the surface or buried at 5 $\mathrm{cm}$ in heat-treated and nontreated soil at $-10,2$, and $20^{\circ} \mathrm{C}$. The fungus survived in 76 to $100 \%$ of kernels. When kernels were incubated at $20^{\circ} \mathrm{C}$, G. zeae was recovered from 83 and $76 \%$ of kernels in heat-treated and nontreated soil, respectively. Perithecia developed on kernels incubated at 20 and $2^{\circ} \mathrm{C}$, but ascospores developed only in perithecia on Fusarium-damaged kernels at $20^{\circ} \mathrm{C}$ on the soil surface. As survival of G. zeae in Fusarium-damaged kernels did not decrease after 24 months, rotations of at least 2 years are necessary to avoid infection of new crops by G. zeae originating from Fusarium-damaged kernels.
\end{abstract}

Additional keywords: decomposition rate, Fusarium graminearum, head blight

Fusarium head blight is an important disease of wheat and other small grains that results in quality and economic losses for the grain industry. The disease is caused by several Fusarium species (22), but the principal pathogen associated with Fusarium head blight in Manitoba is Gibberella zeae (Schwein.) Petch (anamorph $=$ Fusarium graminearum Schwabe) (15). In addition to reduced yield, economic losses arise from the accumulation of the mycotoxin deoxynivalenol (DON), which can make infected grain unfit for human and animal consumption. Milling, baking, and pasta-making qualities are also altered when grain is infected with G. zeae (4). Epidemics of Fusarium head blight have occurred sporadically in eastern Canada since 1927 (28). In 1984, the first outbreak of Fusarium head blight caused by $F$. graminearum was reported in southern Manitoba (6). Since that time, Fusarium head blight epidemics developed in years when favorable environmental conditions occurred. In 1993, Manitoba experienced the wettest summer and the most severe outbreak on record. Losses for the province

Corresponding author: S. A. Inch

E-mail: Sinch@em.agr.ca

Cereal Research Centre, AAFC, Contribution no. 1824.

Accepted for publication 17 October 2002.

Publication no. D-2002-1231-01R

(C) 2003 The American Phytopathological Society were estimated at $\$ 75$ million dollars, and annual losses have since been estimated at approximately $\$ 50$ million $(15,16)$.

Two states of the pathogen exist: the sexual state G. zeae, and the asexual state, $F$. graminearum. Macroconidia are produced by asexual reproduction in sporodochia on infected heads and crop debris (2). These are splash-dispersed by rain and are involved in the secondary infection of wheat heads. Sexual fruiting bodies, perithecia, are formed in the spring on infected crop residue and require rainfall levels greater than $5 \mathrm{~mm}$ to develop $(18,26,28,30)$. Ascospores, which are the primary source of inoculum, are forcibly discharged from perithecia and dispersed by wind 3 to 5 days after a rainfall event $(11,18,26)$. With the increase in no-till or conservation tillage practices (27), large amounts of crop residue remain on the surface of the soil and provide a source of inoculum (5,20,32,33). Macroconidia and perithecia may be observed on residue on or above the soil surface for up to 3 years (20).

Several practices have been suggested to control Fusarium head blight and to reduce inoculum levels. Some of these include crop rotation of wheat and other susceptible small grains with nonhost crops such as canola or alfalfa $(8,25,28)$, fungicide seed treatments $(13,19)$, and plowing under of crop residues to eliminate inoculum by accelerating decomposition and blocking ascospore dispersal (29). G. zeae can survive as a saprophyte on buried crop residue (28) and persist in the soil as chlamydospores for up to 16 months, depending on the soil (24). Soil, host tissue type, and environmental conditions also play an important role in determining rates of residue decomposition and duration of survival $(3,9)$.

A practical recommendation to reduce the potential for downgrading of grain when delivered to the elevator is to increase the air flow and blow the lightweight Fusarium-damaged kernels out the back of the combine during harvest (21). However, the ultimate fate and duration of survival of G. zeae in these kernels is unknown (14). The main objective of the study was to determine the duration of survival of G. zeae in Fusarium-damaged kernels when these are left on the soil surface or buried in the field. In addition, the effects of temperature and soil status (heattreated versus nontreated) on the survival of the pathogen in Fusarium-damaged kernels were examined under controlled conditions.

\section{MATERIALS AND METHODS}

Fusarium-damaged kernels that were white, chalky, and shriveled in appearance were selected from a sample of the hard red spring wheat cultivars AC Domain and Roblin. To determine the species present on the infected samples, 100 Fusariumdamaged kernels per cultivar were surfacedisinfected in a $0.3 \%$ solution of $\mathrm{NaOCl}$ for $1 \mathrm{~min}$. The kernels were afterward placed in a laminar flow cabinet and allowed to dry for $3 \mathrm{~h}$. The Fusariumdamaged kernels were then incubated on potato dextrose agar (PDA) (BBL Cockeysville, MD) amended with streptomycin $(0.1 \%)$ (Sigma Chemical Co., St. Louis, MO) at $20^{\circ} \mathrm{C}$ under continuous fluorescent white light for 5 days. Fusarium species were identified based on colony and spore morphology, using dissecting and compound microscopes at magnifications of $\times 50$ and $\times 400$, respectively, and a standard key (23).

Field studies. Field experimental plots were established at four different locations in Manitoba to examine the survival of $G$. zeae in Fusarium-damaged kernels. The first site was established in 1998 at the Cereal Research Centre (CRC) experimental research farm at Glenlea, Manitoba (MB). This site was supplemented in 1999 with sites at the CRC in Winnipeg MB, at the Morden Research Centre, Morden MB, and at the Manitoba Crop Diversification Centre, Portage la Prairie MB.

In October 1998, at the CRC experimental research farm at Glenlea, 48 nylon 
mesh $(1 \mathrm{~mm})$ bags $(8 \times 8 \mathrm{~cm})$, each containing 50 Fusarium-damaged kernels, were allocated to three soil depths $(0,5$, and $10 \mathrm{~cm}$ ) in a four-replicate randomized complete block design (i.e., 16 bags per burial depth). During burial, the bags were laid flat with the kernels in a single layer to ensure that each had equal exposure to the soil substrate. This experimental design was chosen to provide replication for the recovery of the bags without replacement at each of four sampling intervals. Sampling with the removal of four bags from each burial depth took place every 6 months beginning April 1999 and ending October 2000. The remaining three sample locations in Manitoba were established in October 1999. The overall experimental design at these sites was similar to that used at the CRC, with the exception that 25 Fusarium-damaged kernels were placed in each bag and sampling occurred on a monthly basis from May through September 2000 .

At each sampling time, the retrieved Fusarium-damaged kernels were rinsed with distilled water to remove soil, surface-disinfected in a $0.3 \%$ solution of $\mathrm{NaOCl}$ for $1 \mathrm{~min}$, and then dried for $3 \mathrm{~h}$ in a laminar flow cabinet. The mass of the kernels from each treatment was determined to calculate decay rate (as described below) and then examined for perithecial development using a compound microscope at a magnification of $\times 50$. Four infected kernels were selected at random, and five perithecia were removed to determine ascospore development stage using a compound microscope at a magnification of $\times 400$. Kernels that had perithecia but no ascospores were assigned a ' + '; if ascospores were present in the perithecia, a '++' was assigned; and kernels with no perithecia were given a '-' rating. All kernels were then incubated on PDA amended with streptomycin at $20^{\circ} \mathrm{C}$ under continuous fluorescent white light for 5 days. Fusarium species were identified as described earlier. The number of kernels that yielded G. zeae was recorded.

Main effects of date, location, and burial depth, and their interactions, on isolation of $G$. zeae from kernels from all three locations were determined by a logistic regression using the SAS procedure GENMOD (SAS Institute Inc., Cary, NC). The results are presented as the likelihood ratio statistics of the chi-square distribution. This analysis was also used for the 1998 experiment at Glenlea for date and depth.

Soil samples were collected from the three study locations in September 2000. Surface debris was brushed aside and approximately $20 \mathrm{~g}$ of soil removed from the top $15 \mathrm{~cm}$. This was repeated five times at each of the sample sites. The subsamples were combined in a single paper bag and mixed thoroughly by shaking. Percent sand, silt, and clay of the soils was determined using the hydrometer method (12).
To determine the decomposition rate, a negative exponential decay function was used. For this function, the remaining mass at each sample interval should be expressed as a percentage of the initial dry mass of the kernels. However, desiccation of the kernels used in the field experiment could have potentially resulted in the elimination of $G$. zeae from the samples. Initial mass was therefore estimated from the mean mass of infected kernels that were not buried at the sites. To obtain this value, four replicates of 25 kernels were surface-disinfected in a $0.3 \%$ solution of $\mathrm{NaOCl}$ for 1 min and then dried in a laminar flow cabinet for $3 \mathrm{~h}$. A mean mass for the dried kernels was calculated and used in the decay function. The rate of decomposition $(k)$ was then obtained with the following equation: $k=-[\operatorname{Ln}($ remaining mass at time $t$ /initial mass) $] / t$, where $t$ is the time in days from the date of burial.

In practice, $k$ is obtained from the slope of the linear regression of the log of the percent remaining mass over the period of the experiment. The main effects of burial depths, locations, and sampling time on decomposition rates were determined by arcsine-transformed percent mass remaining values analyzed using the SAS procedure PROC GLM (SAS).

Effects of heat-treated and nontreated soil and temperature on survival of $G$. zeae. A soil mixture consisting of a $3: 1$ mix of Glenlea soil and Turface (Profile Products LLC, Buffalo Grove, IL) was used in this experiment. Half the soil was heat-sterilized at $115^{\circ} \mathrm{C}$ for $2 \mathrm{~h}$ at 14 to 18 atm. Fusarium-damaged kernels selected from severely infected samples of Roblin and AC Domain wheat were placed in nylon mesh $(1 \mathrm{~mm})$ bags $(8 \times 8 \mathrm{~cm})$, with 25 Fusarium-damaged kernels per bag. Sixteen bags were left on the soil surface or buried at $5 \mathrm{~cm}$ in heat-treated or nontreated soil mixture in trays $(30 \times 15 \times$ $10 \mathrm{~cm})$. The trays were incubated in cold rooms at -10 or $2^{\circ} \mathrm{C}$, or in a greenhouse at $20^{\circ} \mathrm{C}$. The trays incubated at $20^{\circ} \mathrm{C}$ were watered with $250 \mathrm{ml}$ of distilled water every week to keep soil moist, and the trays at 2 and $-10^{\circ} \mathrm{C}$ were covered with plastic to prevent the soil from drying out. At each sampling time, four bags per treatment and burial depth were sampled (without replacement) using a predetermined randomization pattern at 6-month intervals for 24 months.

At each sampling time, the retrieved Fusarium-damaged kernels were surfacedisinfected as described above. All kernels from each treatment were weighed, examined for perithecial development, and incubated on PDA amended with streptomycin. Fusarium species were identified as described earlier. The number and percent isolation of $G$. zeae from sampled kernels were recorded.

Main effects of sampling date, temperature, soil treatment, and burial depth and their interactions on isolation of $G$. zeae from kernels were determined by a logistic regression using the SAS procedure GENMOD (SAS). The results are presented as the likelihood ratio statistics of the chi-square probability.

\section{RESULTS}

G. zeae was isolated from $100 \%$ of the AC Domain and 97\% of Roblin kernels before burial. Other species isolated included F. culmorum (W.G. Smith), Epicoccum nigrum Link., and Alternaria spp.

Field studies. G. zeae was isolated from 85 to $100 \%$ of Fusarium-damaged kernels from the soil surface or buried at 5 and 10 $\mathrm{cm}$ after 24 months in the Glenlea study (Table 1). At 24 months (October 2000), Fusarium-damaged kernels left on the soil surface were difficult to retrieve due to the breakdown of the nylon bags. Only 20 kernels of 200 were recovered. Of these, $17(85 \%)$ yielded $G$. zeae. Of the main effects, only sampling date had a significant effect. However, this effect was probably less associated with date of sampling than with the low numbers of kernels recovered due to degradation of the nylon mesh bags that had been left exposed to the elements for 24 months. Except for the last sample, isolation from the surface ranged from 97 to $100 \%$ of kernels. The effects of depth and the date-by-depth interactions were not significant.

Table 1. Isolation of Gibberella zeae from Fusarium-damaged kernels (FDK) placed at the soil surface $(0 \mathrm{~cm})$ or buried at 5 and $10 \mathrm{~cm}$ at Glenlea, Manitoba, October 1998

\begin{tabular}{lcccc}
\hline Time of sampling & $\begin{array}{c}\text { FDK depth } \\
(\mathbf{c m})\end{array}$ & $\begin{array}{c}\text { FDK recovered } \\
(\mathbf{n o .})^{\mathbf{a}}\end{array}$ & $\begin{array}{c}\text { Kernels with } \\
\text { G. } \text { zeae }(\mathbf{n o})\end{array}$ & $\begin{array}{c}\text { FDK producing } \\
\text { G. zeae }(\%)\end{array}$ \\
\hline April 1999 & 0 & 198 & 194 & 99 \\
& 5 & 201 & 195 & 97 \\
October 1999 & 10 & 200 & 193 & 97 \\
& 0 & 190 & 187 & 98 \\
April 2000 & 5 & 195 & 195 & 100 \\
& 10 & 181 & 181 & 100 \\
& 0 & 202 & 201 & 100 \\
October 2000 & 5 & 181 & 180 & 100 \\
& 10 & 175 & 175 & 100 \\
& 0 & 20 & 17 & 95 \\
& 5 & 157 & 153 & 99 \\
\hline
\end{tabular}

${ }^{a}$ Out of 200 FDK (sum of four replicates, 50 kernels per replicate). 
The soil at Morden was characterized as a sandy loam, at Portage a silty loam, and at Winnipeg a silty clay loam. At Morden, Portage la Prairie, and Winnipeg (1999 test), recovery of Fusariumdamaged kernels was high following the winter and monthly sampling (a total of 11 months). G. zeae was recovered from 97 to $100 \%$ of kernels (Table 2). The main effect of location and the interaction between location and depth were not significant. Date had the most significant effect on isolation of $G$. zeae; $F$ was significant at $P=0.0001$ (Table 3). The significant interaction of date by depth was plotted (Fig. 1). In the first three sample times, it was clear that survival of G. zeae in kernels was lower at $10 \mathrm{~cm}$ than on the surface or at $5 \mathrm{~cm}$. In August and September, survival ranged from 98 to $100 \%$. The kernels buried at 5 and $10 \mathrm{~cm}$ from all three locations had a significantly higher rate of decomposition than the Fusarium-damaged kernels left on the soil surface $(P=0.001)$. After 331 days, the biomass of Fusarium-damaged kernels located on the surface, at all locations, had decreased by approximately $50 \%$, whereas the kernels buried at 5 and $10 \mathrm{~cm}$ were almost entirely decomposed, with less than $7 \%$ of the original mass remaining at the end of the study (Fig. 2).

Table 2. Isolation ${ }^{\mathrm{a}}$ of Gibberella zeae from Fusarium-damaged kernels (FDK) left at the soil surface $(0 \mathrm{~cm})$ or buried at 5 and $10 \mathrm{~cm}$ in October 1999 at Morden, Portage la Prairie, and Winnipeg, Manitoba, and sampled in 2000

\begin{tabular}{lcccccc}
\hline & & \multicolumn{5}{c}{ Sampling date } \\
\cline { 3 - 7 } Location & FDK depth $(\mathbf{c m})$ & May & June & July & August & September \\
\hline Morden & 0 & 94 & 98 & 98 & 100 & 97 \\
& 5 & 99 & 99 & 100 & 100 & 97 \\
Portage & 10 & 97 & 98 & 100 & 100 & 100 \\
& 0 & 91 & 99 & 100 & 99 & 98 \\
& 5 & 96 & 100 & 100 & 99 & 100 \\
Winnipeg & 10 & 94 & 99 & 100 & 98 & 100 \\
& 0 & 96 & 97 & 98 & 100 & 100 \\
& 5 & 91 & 100 & 100 & 100 & 98 \\
& 10 & 96 & 100 & 100 & 100 & 100 \\
\hline
\end{tabular}

a Percentage of Fusarium-damaged kernels from which Gibberella zeae was isolated (based on average values of four replicates of $50 \mathrm{FDK}$ ).

Table 3. Likelihood ratio statistics for effects of location, depth of burial, and time of sampling date on isolation of Gibberella zeae from Fusarium-damaged kernels left at the soil surface $(0 \mathrm{~cm})$ or buried at 5 and $10 \mathrm{~cm}$ in October 1999 at Morden, Portage la Prairie, and Winnipeg, Manitoba, and sampled in 2000

\begin{tabular}{lccc}
\hline Source & df & Chi-square & P > chi-square \\
\hline Location & 2 & 1.23 & 0.5407 \\
Date & 4 & 162.06 & $<0.0001$ \\
Location*date & 8 & 38.9 & $<0.0001$ \\
Depth & 2 & 14.53 & 0.0007 \\
Location*depth & 4 & 6.19 & 0.1857 \\
Date*depth & 8 & 20.43 & 0.0088 \\
Location*date*depth & 16 & 49.57 & $<0.0001$ \\
\hline
\end{tabular}

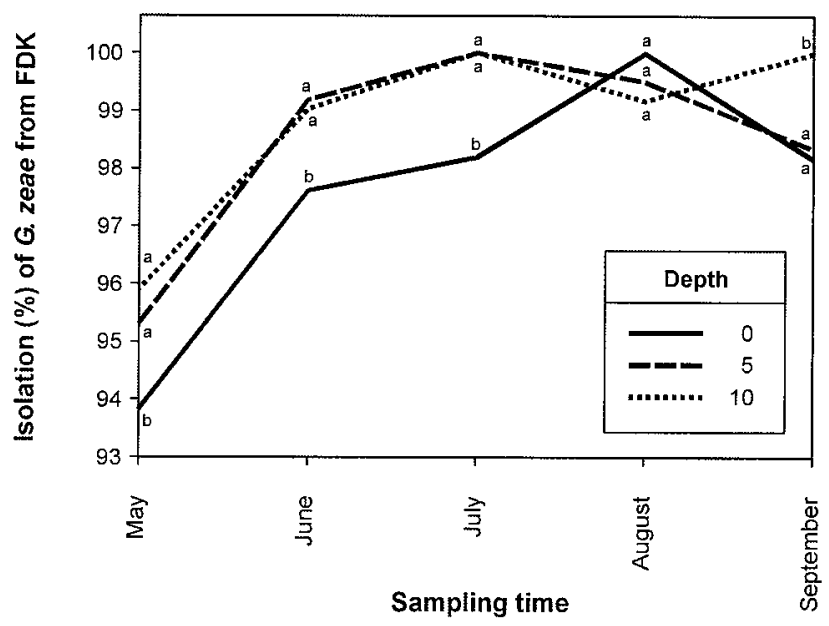

Fig. 1. Isolation of Gibberella zeae from Fusarium-damaged kernels (FDK) left at the soil surface $(0 \mathrm{~cm})$ or buried at 5 and $10 \mathrm{~cm}$. Sampling time data points with the same letter are not significantly different at $P=0.05$ (based on likelihood ratio statistics). Values are percentages of all kernels sampled.
Effects of heat-treated versus nontreated soil and temperature on survival of $G$. zeae. Under controlled conditions, sampling date and depth of burial did not influence isolation of $G$. zeae in kernels sampled from 2 and $-10^{\circ} \mathrm{C}$; survival ranged from 98 to $100 \%$ after 24 months (Table 4). Isolations of G. zeae in Fusarium-damaged kernels located on the surface at $20^{\circ} \mathrm{C}$ were 92 and $96 \%$ in the heattreated and nontreated soil, respectively, whereas isolation from kernels buried at 5 $\mathrm{cm}$ significantly decreased after 24 months, with values of 83 and $76 \%$, respectively (Table 4). The likelihood ratio statistics for Type 3 analysis from a logistic regression are presented (Table 5). Temperature followed by date and the temperature-by-date interaction were the most important effects on isolation, as indicated by chi-square and probability values. Position (soil surface or buried) was also a significant factor (Table 5).

Other fungal species isolated from 1 to $24 \%$ of the kernels, under both field and controlled conditions, included $F$. culmorum, F. equiseti (Corda) Sacc., Epicoccum nigrum, Alternaria spp., and Penicillium spp. Link.

Perithecial development. Perithecial production was observed on kernels from all field locations and treatments. Under field conditions at Glenlea, perithecia were first noted in April 1999 after 6 months on Fusarium-damaged kernels both at the soil surface and buried at 5 and $10 \mathrm{~cm}$. However, no ascospores were detected. The kernels buried at Winnipeg, Morden, and Portage la Prairie in October 1999 did not develop perithecia until June 2000 after 9 months. Kernels at all burial depths developed perithecia, but ascospores developed only in perithecia on the kernels left at the soil surface (Table 6). Under controlled conditions, kernels exposed to 20 and $2{ }^{\circ} \mathrm{C}$, either on the soil surface or buried at $5 \mathrm{~cm}$, developed perithecia, and only those incubated at $20^{\circ} \mathrm{C}$ formed ascospores. A few perithecia formed on buried kernels that were incubated at $-10^{\circ} \mathrm{C}$, but none formed on kernels at the soil surface at this temperature (Table 7).

\section{DISCUSSION}

In Manitoba, G. zeae survived for at least 24 months in Fusarium-damaged kernels left on the soil surface or buried. In a previous study, G. zeae survived at least 2 years longer in crop residues on the soil surface than in residues that were buried (20). The authors suggest that high soil water potentials were responsible for the decline in survival. Different regions within Canada have various levels of rainfall during the growing season. Typically, Manitoba experiences hot, dry summers, which may partly explain the extended survival of G. zeae in buried kernels. Fusarium-damaged kernels may act as a source of inoculum leading to disease develop- 
ment when susceptible crops are planted in contaminated fields. Nearly all the intact kernels harbored $G$. zeae; this suggests that the amount of kernels being spread on the field during harvest is an important inocu- lum load consideration. Transmission of $G$. zeae from infected seeds to wheat stems has been directly related to disease development in winter wheat (10). Chongo et al. (5) found that root and crown rot severity

A)

B)
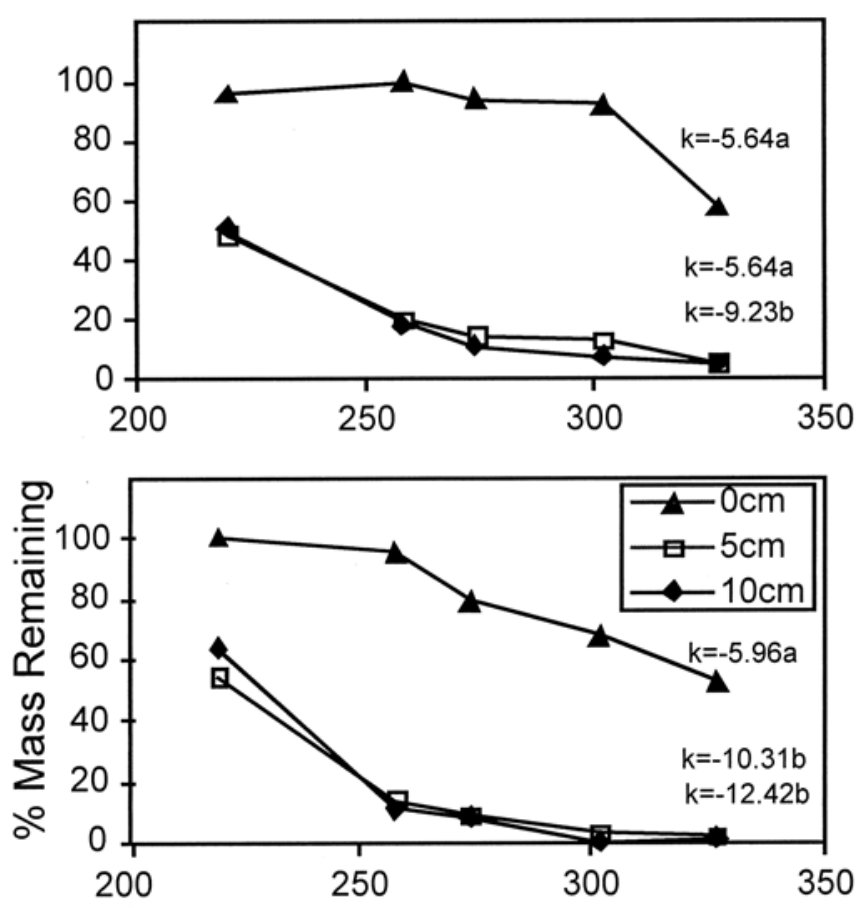

C)

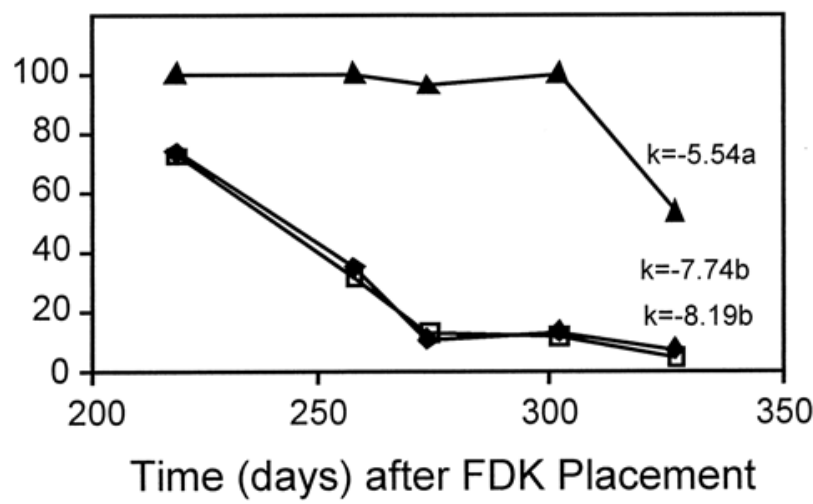

Fig. 2. Decomposition rates ( $k$ ) and percent mass remaining of Fusarium-damaged kernels (FDK) after 11 months at the soil surface $(0 \mathrm{~cm})$ or buried at 5 and $10 \mathrm{~cm}$ from A, Winnipeg, B, Portage la Prairie, and $\mathbf{C}$, Morden, Manitoba. Slopes with the same letter are not significantly different at $P=0.001$.

increased, and seedling emergence decreased, in cereal and noncereal crops planted in soils inoculated with $F$. graminearum-infected seed. Kernels could potentially have been colonized after being placed in the soil. This may explain the slight increase in isolation of G. zeae from kernels left in the field. Cotten and Munkvold (7) found that maize residues were colonized subsequently after placement by other Fusarium species present in the soil.

In this study, soil type did not appear to influence the short-term survival of G. zeae in Fusarium-damaged kernels. In Australian studies, Burgess and Griffin (3) found that soil type influenced survival of $G$. zeae. The rate at which host tissues decompose will influence the survival of $G$. zeae. The Fusarium-damaged kernels that were buried decomposed at a faster rate than those left at the soil surface. Kernels that are buried have a greater surface area in contact with soil microorganisms that may influence the decomposition rate. $G$. zeae is a poor competitor with other soil microflora and requires a suitable substrate within the soil to survive (24). Once a residue decomposes, the fungus needs to colonize a new substrate. Recovery of $G$. zeae on wheat residues was found to correspond to the rate of decomposition (9). Furthermore, survival of $G$. zeae was longer on tissues that break down slowly, and consequently, recovery of G. zeae after 52 weeks was higher on nodal than on internodal tissues, 94 and $0 \%$, respectively (3). Other environmental factors such as temperature, rainfall, soil temperature, and soil moisture levels may influence rate of decomposition and fungal survival as well.

Temperature also played a role in the survival of G. zeae. Survival was lower at $20^{\circ} \mathrm{C}$ than in kernels incubated at colder temperatures. Earlier studies have reported a decrease in the viability of G. zeae on grain stored at the higher temperature (17). Cold temperature storage is recommended to control insect pests, mites, and fungal growth, but at low temperatures, the survival of G. zeae is improved. If contaminated seed is used after cold temperature

Table 4. Isolation ${ }^{\mathrm{a}}$ of Gibberella zeae from Fusarium-damaged kernels (FDK) placed on the soil surface or buried at $10 \mathrm{~cm}$ in heat-treated or nontreated soils at 20,2 , and $-10^{\circ} \mathrm{C}$

\begin{tabular}{|c|c|c|c|c|c|c|}
\hline \multirow[b]{2}{*}{ Temperature $\left({ }^{\circ} \mathrm{C}\right)$} & \multirow[b]{2}{*}{ Position of FDK } & \multirow[b]{2}{*}{ Soil treatment } & \multicolumn{4}{|c|}{ Sampling date } \\
\hline & & & May 1999 & November 1999 & May 2000 & November 2000 \\
\hline \multirow[t]{4}{*}{20} & Surface & Heat treated & 100 & 96 & 94 & 92 \\
\hline & & Nontreated & 99.5 & 99 & 95 & 96 \\
\hline & Buried & Heat treated & 100 & 87 & 85 & 83 \\
\hline & & Nontreated & 91.9 & 87 & 80 & 76 \\
\hline \multirow[t]{4}{*}{2} & Surface & Heat treated & 99.5 & 100 & 99 & 100 \\
\hline & & Nontreated & 100 & 100 & 100 & 100 \\
\hline & Buried & Heat treated & 100 & 100 & 100 & 100 \\
\hline & & Nontreated & 99.5 & 100 & 99 & 100 \\
\hline \multirow[t]{4}{*}{-10} & Surface & Heat treated & 99.5 & 100 & 100 & 99 \\
\hline & & Nontreated & 100 & 100 & 100 & 100 \\
\hline & Buried & Heat treated & 99.5 & 98 & 98 & 100 \\
\hline & & Nontreated & 99.5 & 98 & 100 & 98 \\
\hline
\end{tabular}

a Percentage of Fusarium-damaged kernels from which Gibberella zeae was isolated (based on average values of four replicates of 25 FDK). 
storage, seedling survival in the spring may be compromised because of the presence of viable G. zeae $(17,19)$.

Perithecia and ascospores matured on kernels left on the soil surface, providing a potential source of inoculum to infect the spikes of small-grain crops. When environmental conditions are favorable for the production of perithecia on kernel residues, inoculum levels will increase. In the field, perithecia did not form until the following spring, indicating that in Manitoba they did not function as over-wintering survival structures as first suggested by Atanasoff
(1). At Glenlea, abundant perithecia were observed on the Fusarium-damaged kernels located on the surface or buried at 5 or $10 \mathrm{~cm}$ in April of both years, but no ascospores were detected. At Portage la Prairie, Morden, and Winnipeg, perithecia did not develop until June 2000 on Fusariumdamaged kernels left on the soil surface. Konga and Sutton (20) found similar results; they noted abundant perithecial production on wheat grains sampled in June from the soil surface. However, no perithecia formed on buried residues. Perithecia and ascospore formation, under controlled

Table 5. Likelihood ratio statistics for effects of temperature, position, soil treatment, and time of sampling (date) on isolation of Gibberella zeae from Fusarium-damaged kernels placed on the soil surface or buried at $10 \mathrm{~cm}$ in heat-treated or nontreated soils at 20,2 , and $-10^{\circ} \mathrm{C}$

\begin{tabular}{lccc}
\hline Source & df & Chi-square & P $>$ chi-square \\
\hline Temperature & 2 & 320.23 & $<0.0001$ \\
Position & 1 & 44.36 & $<0.0001$ \\
Temperature*position & 2 & 52.72 & $<0.0001$ \\
Soil & 1 & 0.1 & 0.7562 \\
Temperature*soil & 2 & 1.55 & 0.4597 \\
Position*soil & 1 & 8.95 & 0.0028 \\
Temperature*position*soil & 2 & 9.47 & 0.0088 \\
Date & 4 & 122.46 & $<0.0001$ \\
Temperature*date & 8 & 178.93 & $<0.0001$ \\
Position*date & 4 & 14.36 & 0.0062 \\
Temperature*position*date & 8 & 13.63 & 0.0918 \\
Soil*date & 4 & 6.21 & 0.1838 \\
Temperature*soil*date & 8 & 17.66 & 0.0239 \\
Position*soil*date & 4 & 4.87 & 0.3012 \\
Temperature*position*soil*date & 8 & 14.88 & 0.061 \\
\hline
\end{tabular}

Table 6. Perithecial and ascospore production on Fusarium-damaged kernels (FDK) at soil surface (0 $\mathrm{cm}$ ) or buried at 5 and $10 \mathrm{~cm}$ at Morden, Portage la Prairie, and Winnipeg, Manitoba

\begin{tabular}{lcccccc}
\hline & & \multicolumn{5}{c}{ Perithecial production } \\
\cline { 3 - 7 } Location $^{\mathbf{a}}$ & FDK depth (cm) & $\mathbf{2 0 0 0}$ & $\mathbf{2 0 0 0}$ & $\mathbf{2 0 0 0}$ & $\mathbf{2 0 0 0}$ & $\mathbf{2 0 0 0}$ \\
\hline Morden & 0 & - & ++ & ++ & ++ & ++ \\
& 5 & - & + & + & + & + \\
\multirow{3}{*}{ Portage } & 10 & - & - & + & + & + \\
& 0 & - & ++ & ++ & ++ & ++ \\
\multirow{2}{*}{ Winnipeg } & 5 & - & + & + & + & + \\
& 10 & - & + & + & + & + \\
& 0 & - & ++ & ++ & ++ & ++ \\
& 5 & - & + & + & + & + \\
& 10 & - & - & - & + & + \\
\hline
\end{tabular}

${ }^{a}$ Test initiated October 1999.

${ }^{\mathrm{b}}$ Rating scale: $-=$ no perithecia, $+=$ perithecia and no ascospores, $++=$ perithecia with ascospores.

conditions, may have been influenced by temperature as well as moisture levels. Optimal temperatures for the production of perithecia range from 15 to $28.5^{\circ} \mathrm{C}(31)$, and for ascospore production, from 25 to $28^{\circ} \mathrm{C}(28)$.

Under field conditions, ascospores developed only on Fusarium-damaged kernels left on the soil surface. Levels of inoculum from these small residue fragments are unknown but may be significant from highly infested fields where large numbers of infected kernels were discarded. As ascospores are wind dispersed, their formation in the soil would have no advantage to the pathogen. However, if fragments of buried infected kernels are brought to the surface through tillage operations, these may colonize other surface debris from which perithecia and ascospores may develop to infect the current crop.

In conclusion, isolation of G. zeae from Fusarium-damaged kernels in Manitoba was not diminished after 24 months and was not influenced by burial depth, suggesting that rotations of at least 2 years are necessary to avoid infection of new crops by G. zeae from Fusarium-damaged kernels. Temperature also influenced the survival of G. zeae. At high temperatures, survival was found to decrease after 24 months. Low temperatures tended to extend the viability of G. zeae in Fusariumdamaged kernels. Perithecia and ascospore development occurred mainly on Fusarium-damaged kernels located on the surface of the soil, providing an inoculum source that could contribute to disease outbreaks. On buried Fusarium-damaged kernels, perithecia production was low, but fungal survival was not compromised. Depth of Fusarium-damaged kernels influenced the rate of decomposition. Once residues decompose, duration of survival may be reduced, but under Manitoba conditions isolation of $G$. zeae from kernels was still possible 24 months after burial.

\section{ACKNOWLEDGMENTS}

Funding for this project was provided by a research grant from the Agri-Food Research and Development Initiative (ARDI). Also, thanks to Ron Kaethler, Uwe Kromer, and Kevin Morgan for

Table 7. Perithecial and ascospore production on Fusarium-damaged kernels (FDK) incubated at 20,2 , and $-10^{\circ} \mathrm{C}$

\begin{tabular}{|c|c|c|c|c|c|c|}
\hline \multirow[b]{2}{*}{ Temperature $\left({ }^{\circ} \mathbf{C}\right)$} & \multirow[b]{2}{*}{ Position of FDK } & \multirow[b]{2}{*}{ Soil treatment } & \multicolumn{4}{|c|}{ Perithecial production $^{a}$} \\
\hline & & & May 1999 & November 1999 & May 2000 & November 2000 \\
\hline \multirow[t]{4}{*}{20} & Surface & Heat treated & ++ & ++ & ++ & ++ \\
\hline & & Nontreated & ++ & ++ & ++ & ++ \\
\hline & Buried & Heat treated & ++ & ++ & ++ & ++ \\
\hline & & Nontreated & ++ & ++ & ++ & ++ \\
\hline \multirow[t]{4}{*}{2} & Surface & Heat treated & + & + & + & + \\
\hline & & Nontreated & + & + & + & + \\
\hline & Buried & Heat treated & + & + & + & + \\
\hline & & Nontreated & + & + & + & + \\
\hline \multirow[t]{4}{*}{-10} & Surface & Heat treated & - & - & - & - \\
\hline & & Nontreated & - & - & - & - \\
\hline & Buried & Heat treated & + & + & + & + \\
\hline & & Nontreated & + & + & + & + \\
\hline
\end{tabular}

\footnotetext{
${ }^{a}$ Rating scale: $-=$ no perithecia,$+=$ perithecia and no ascospores, $++=$ perithecia with ascospores.
} 
their technical assistance and D. Walker and S. M. Woods for their statistical advice.

\section{LITERATURE CITED}

1. Atanasoff, D. 1920. Fusarium-blight (scab) of wheat and other cereals. J. Agric. Res. 20:132.

2. Booth, C. 1971. The Genus Fusarium. Commonwealth Mycological Institute, Kew, Surrey, England.

3. Burgess, W. L., and Griffin, D. M. 1968. The recovery of Gibberella zeae from wheat straws. Aust. J. Exp. Agric. Anim. Husb. 8:364-370.

4. Charmley, L. L., Rosenberg, A., and Trenholm, H. L. 1994. Factors responsible for economic losses to Fusarium mycotoxin contaminated grain, foods, and feedstuffs. Pages 471-486 in: Mycotoxins in Grain: Compounds Other Than Aflatoxins. J. D. Miller and H. L. Trenholm, eds. Eagan Press, St. Paul, MN.

5. Chongo, G., Gossen, B. D., Kutcher, H. R., Gilbert, J., Turkington, T. K., Fernandez, M. R., and McLaren, D. 2001. Reaction of seedling roots of 14 crop species to Fusarium graminearum from wheat heads. Can. J. Plant. Pathol. 23:132-137.

6. Clear, R. M., and Abramson, D. 1986. Occurrence of Fusarium head blight and deoxynivalenol (vomitoxin) in two samples of Manitoba wheat in 1984. Can. Plant Dis. Surv. 66:9-11.

7. Cotten, T. K., and Munkvold, G. P. 1998. Survival of Fusarium moniliforme, F. proliferatum, and $F$. subglutinans in maize stalk residues. Phytopathology 88:550-555.

8. Dickson, J. G. 1956. Diseases of Field Crops. McGraw-Hill Book Co., New York.

9. Dill-Macky, R., Sims, A. L., and Pereyra, S. A. 1998. Survival of Fusarium graminearum in wheat residue. Pages 41-43 in: Proc. 1998 National FHB Forum. Michigan State University, East Lansing.

10. Duthie, J. A., and Hall, R. 1987. Transmission of Fusarium graminearum from seed to stems of winter wheat. Plant Pathol. 36:33-37.

11. Fernando, W. G. D., Paulitz, T. C., Seaman,
W. L., Dutilleul, P., and Miller, J. D. 1997. Head blight gradients caused by Gibberella zeae from area sources of inoculum in wheat field plots. Phytopathology 87:414-421.

12. Foth, H. D., Jacobs, H. S., and Withee, L. V. 1974. Laboratory Manual for Introductory Soil Science, 4th ed. W. C. Brown, Dubuque, IA

13. Gilbert, J., and Tekauz, A. 1995. Effect of fusarium head blight and seed treatment on germination, emergence, and seedling vigour of spring wheat. Can. J. Plant Pathol. 17:252259.

14. Gilbert, J., and Tekauz, A. 2000. Review: Recent developments in research on fusarium head blight of wheat in Canada. Can. J. Plant Pathol. 22:1-8

15. Gilbert, J., Tekauz, A., Kaethler, R., Gold, J., Mueller, E., Kromer, U., Morgan, K., and DiCarlo, A. 2001. 2000 fusarium head blight survey of spring wheat in Manitoba and eastern Saskatchewan. Can. Plant Dis. Surv. 81:89.

16. Gilbert, J., Tekauz, A., Mueller, E., and Kromer, U. 1994. Occurrence of Fusarium head blight in Manitoba in 1993. Can. Plant Dis. Surv. 74:77-78

17. Gilbert, J., Tekauz, A., and Woods, S. M. 1997. Effect of storage on viability of Fusarium head blight-affected spring wheat seed. Plant Dis. 81:159-162.

18. Inch, S. A. 2001. An Epidemiological Study of Fusarium Head Blight (FHB) of Wheat Caused by Gibberella zeae. MSc. thesis. University of Manitoba, Winnipeg, Canada.

19. Jones, R. K. 1999. Seedling blight development and control in spring wheat damaged by Fusarium graminearum Group 2. Plant Dis. 83:1013-1018

20. Konga, E. B., and Sutton, J. C. 1988. Inoculum production and survival of Gibberella zeae in maize and wheat residues. Can. J. Plant Pathol. 10:232-239.

21. Manitoba Agriculture and Food. 2002. Pest Management-Plant Diseases Fusarium Head Blight (Wheat and Barley) Manitoba Agriculture and Food. Online publication.

22. Miller, J. D. 1994. Epidemiology of Fusarium ear disease of cereals. Pages 19-36 in: Mycotoxins in Grain: Compounds Other Than Aflatoxins. J. D. Miller and T. H. Trenholm, eds. Eagan Press, St. Paul, MN

23. Nelson, P. E., Tousson, T. A., and Marasas, W F. O. 1983. Fusarium Species-An Illustrated Manual for Identification. Pennsylvania State University Press, University Park.

24. Nyvall, R. F. 1970. Chlamydospores of Fusarium roseum 'Graminearum' as survival structures. Phytopathology 60:1175-1177.

25. Parry, D., Jenkinson, P., and McLeod, L. 1995. Fusarium ear blight (scab) in small grain cereals-A review. Plant Pathol. 44:207238.

26. Paulitz, T. C. 1996. Diurnal release of ascospores by Gibberella zeae in inoculated wheat plots. Plant Dis. 80:674-678.

27. Sumner, D. R., Doupnik, B., and Boosalis, M G. 1981. Effects of reduced tillage and multiple cropping on plant disease. Annu. Rev. Phytopathol. 19:167-187.

28. Sutton, J. C. 1982. Epidemiology of wheat head blight and maize ear rot caused by Fusarium graminearum. Can. J. Plant Pathol. 4:195-209.

29. Teich, A. H., and Hamilton, J. R. 1985. Effects of cultural practices, soil phosphorus, potassium and $\mathrm{pH}$ on the incidence of Fusarium head blight and DON levels in wheat. Appl. Environ. Microbiol. 46:1429-1431.

30. Trail, F., Schaupp, J., Platt, C., and Jarosz, M. 1997. Spatio-temporal aspects of inoculum development for wheat head scab caused by Gibberella zeae. Page 64 in: Proc. 1997 National FHB Forum. St. Paul, MN.

31. Tschanz, A. T., Horst, R. K., and Nelson, P. E. 1976. The effect of environment on sexual reproduction of Gibberella zeae. Mycologia 68:327-340.

32. Warren, H. L., and Kommedahl, T. 1973 Fertilization and wheat refuse effects on Fusarium species associated with wheat roots in Minnesota. Phytopathology 63:103-108.

33. Windels, C. E., and Kommedahl, T. 1984. Late-season colonization and survival of Fusarium graminearum group II in cornstalks in Minnesota. Plant Dis. 68:791-793. 